\title{
JOURNAL
}

of Health Inequalities

\section{Prevalence of hypertension in Polish population of PURE Poland study}

\author{
Andrzej Szuba 1,2, Helena Martynowicz ${ }^{3}$, Katarzyna Zatońska ${ }^{4}$, Rafał llow ${ }^{5}$, Bożena Regulska-llow ${ }^{6}$, \\ Dorota Różańska ${ }^{6}$, Maria Wołyniec ${ }^{4}$, Katarzyna Połtyn-Zaradna ${ }^{4}$, Witold A. Zatoński ${ }^{7}, 8$ \\ 'Department of Internal Medicine, $4^{\text {th }}$ Military Hospital in Wroclaw, Poland \\ 2Division of Angiology, Wroclaw Medical University, Wroclaw, Poland \\ ${ }^{3}$ Department and Clinic of Internal and Occupational Diseases and Hypertension, Wroclaw Medical University, \\ Wroclaw, Poland \\ ${ }^{4}$ Department of Social Medicine, Wroclaw Medical University, Wroclaw, Poland \\ ${ }^{5}$ Department of Food Science and Dietetics, Wroclaw Medical University, Wroclaw, Poland \\ ${ }^{6}$ Department of Dietetics, Wroclaw Medical University, Wroclaw, Poland \\ ${ }^{7}$ Health Promotion Foundation, Nadarzyn, Poland \\ ${ }^{8}$ Higher Vocational State School in Kalisz, Poland
}

\begin{abstract}
Introduction: Hypertension is the most common risk factor for cardiovascular disease and is a significant predictor of premature death and cardiovascular disability. The aim of this cohort study was to evaluate prevalence of hypertension and cardiovascular risk factors in studied population of Lower Silesia province in Poland.

Material and methods: Presented results are a part of PURE project. The study group included 2,044 inhabitants Lower Silesia province. Data collection included clinical history, anthropometric data, blood pressure, and serum glucose. Prevalence, awareness, and treatment of hypertension were evaluated.

Results: $60.3 \%$ of studied population were hypertensive. Hypertension was more prevalent in studied men $(70.63 \%)$ than in women (57.24\%). Education had a significant impact on prevalence of hypertension and the highest prevalence of hypertension was observed in the least educated group. Hypertension was undiagnosed in $48.5 \%$ of studied population. Significantly, more men than women had undiagnosed hypertension (53.4 vs. 44.3 ). The prevalence of undiagnosed hypertension significantly increased with the education level.

Conclusions: The studied group had high prevalence of hypertension (60.3\%). Hypertension was less frequent and better diagnosed in studied women than in men. Level of education had significant impact on prevalence and awareness of hypertension.
\end{abstract}

KEY WORDS: hypertension, prospective study, rural, cohort study, urban.

\section{KEY FINDINGS}

1. The studied group had high prevalence of hypertension (60.30\%).

2. Hypertension was less frequent in studied women than in men.

3. The highest percent of undiagnosed hypertension was at younger, well educated, male urban dwellers.

ADDRESS FOR CORRESPONDENCE: Andrzej Szuba, Department of Internal Medicine, $4^{\text {th }}$ Military Hospital in Wroclaw, 5 Weigla Street, 50-981 Wroclaw, Poland, e-mail: andrzej.szuba@umed.wroc.pl 


\section{INTRODUCTION}

Hypertension is the most common risk factor for cardiovascular disease and is a significant predictor of premature death and cardiovascular disability [1]. Several risk factors of hypertension have been identified. Age, gender, obesity, lifestyle (diet, physical activity), and stress are considered to be a major risk factor [2]. Hypertensive individuals frequently have additional cardiovascular risk factors e.g. obesity, diabetes, dyslipidemia, and insulin resistance $[3,4]$. The pathogenesis of hypertension is known to involve endothelium dysfunction, renin-angiotensin-aldosterone (RAA) system, sympathetic system, and oxidative stress, however, a complete understanding of the causes for hypertension and its high prevalence remains unclear.

Hypertension is the known risk factor for stroke and coronary artery disease. Diabetes mellitus and hypertension are two of the most common diseases, and the frequency of both diseases increases with the age [5]. The prevalence of hypertension in the diabetic population is 1.5-3 times higher than that of non-diabetic agematched groups [6]. Hypertension in diabetic patients causes a significant increase in the risk of cardiovascular events [7].

Medical treatment can start with a single antihypertensive drug. If the target blood pressure values cannot be reached under monotherapy, a combination therapy should be recommended. The guidelines published by the ESH/ESC (European Society of Hypertension/ European Society of Cardiology) recommend initiation of monotherapy in patients with first-degree arterial hypertension, mild/moderate global cardiovascular risk, or a target blood pressure $<140 / 90 \mathrm{mmHg}$. Combination therapy is suggested for patients with second-degree or more arterial hypertension, high or very high global cardiovascular risk, or a target blood pressure $<130 / 80 \mathrm{mmHg}[8,9]$.

Hypertension prevalence varies between high and low income countries $[10,11]$. According to NATPOL survey carried out in 2002 in the Polish population, 29\% of men and $29 \%$ of women over 18 years of age suffered from hypertension. Optimum pressure was found in $20 \%$ people, a high normal blood pressure of $29 \%$ of [12] The recent survey NATPOL 2011 reveal high prevalence of hypertension of $32 \%$, and only in about $26 \%$ of all hypertensive patient's blood pressure is well controlled [13]. However, the PONS study revealed even higher hypertension prevalence of $67 \%$ in polish population in Kielce province [14].

Thus, hypertension is emerging as a major health problem. Despite its magnitude, hypertension is one of the most preventable risk factors for cardiovascular diseases; it can be easily detected and it can be effectively treated. Identifying factors associated with the prevalence, awareness, management, and hypertension control is crucial to prevent the cardiovascular morbid- ity and mortality. Epidemiological studies are urgently needed to assess the prevalence of hypertension and to plan preventive strategies to promote health among the populations.

The objectives of the present study were to describe the prevalence, awareness, treatment of hypertension, and to examine factors associated with these endpoints, among the adult population residing in Lower Silesia province. Additionally, they were focusing on associations between hypertension tendencies and selected demographic variables, including gender and indicators of socioeconomic status. Finally, they've evaluated identification of cardiovascular risk factors in population of Lower Silesia province.

\section{MATERIAL AND METHODS}

Presented results are a part of Prospective Urban Rural Epidemiology Study (PURE). The PURE Poland sub-study is an open-ended prospective cohort study of inhabitants of Lower Silesian in Poland consisting of 2,036 persons $(1,282$ women aged $54.7 \pm 6.7, \min 30$, max 85 years, and 754 men $54.3 \pm 10$, min 32 , max 80 years). All subject were volunteers who agreed to participate in the PURE study. All participants were fully informed about the objectives and procedures of the study and all signed an informed consent form.

The study was conducted between 2007 and 2010 . There were 826 rural dwellers and 1,210 urban dwellers. A structured, pretested schedule was used to collect the data with regards to the socio-demographic characteristics (age, gender, and the socioeconomic status). Blood pressure measurements were carried out with an automated oscillometric device (Omron Corporation, Tokyo, Japan).

Patients were advised to sit quietly and rest for $5 \mathrm{~min}$ utes before measurements. The appropriate cuff size was selected. The second reading was taken after 5 minutes from the first and the third reading after next 5 minutes. The average of three measurements was used to diagnose hypertension, according to the ESC criteria (systolic blood pressure 140 or above and/or diastolic blood pressure $90 \mathrm{mmHg}$ or above). Hypertension was considered controlled if objectives in the ESH/ESC Guidelines were met (blood pressure $<140 / 90 \mathrm{mmHg}$ ) [9]. Resting heart rate was measured after 5-minute inactive period.

In the description, 17 people whose data was missing were not included.

This study was approved by the Polish Ethics Committee: No. KB-443/2006.

\section{RESULTS}

2,019 urban and rural dwellers were studied. $60.28 \%$ of studied population were hypertensive. $8.17 \%$ studied population had optimal blood pressure, $13.67 \%$ normal blood pressure, and $17.89 \%$ high normal blood pressure. 
TABLE 1. Categories of hypertension due to gender

\begin{tabular}{|l|c|c|c|c|}
\hline Blood pressure & Women & Men & All & $P\left(\chi^{2}\right)$ \\
\hline Optimal & $11.14 \%$ & $3.19 \%$ & $8.17 \%$ & \\
\hline Normal & $17.46 \%$ & $7.30 \%$ & $13.67 \%$ & \\
\hline High normal & $19.19 \%$ & $15.67 \%$ & $17.88 \%$ & \\
\hline Hypertension grade 1 & $13.67 \%$ & $17.80 \%$ & $15.21 \%$ & \\
\hline Hypertension grade 2 & $10.03 \%$ & $17.40 \%$ & $12.78 \%$ & \\
\hline Hypertension grade 3 & $5.61 \%$ & $10.23 \%$ & $7.33 \%$ & \\
\hline Isolated systolic & $22.90 \%$ & $28.41 \%$ & $24.96 \%$ & 0.00001 \\
\hline
\end{tabular}

The prevalence of hypertension was $61.02 \%$ in urban dwellers and $59.16 \%$ in rural dwellers. Hypertension was more prevalent among men than women $(73.85 \%$ vs. $52.22 \%$ ). Table 1 shows the number of participants, allocated to the different categories of the WHO/ISH classification. The highest prevalence exists in the subcategories isolated systolic hypertension (27.30\%) and 1 grade hypertension (15.21\%). Only $39.72 \%$ of the hypertensive participants and more women $(47.79 \%)$ than men (26.17\%) had blood pressures lower than $140 / 90 \mathrm{mmHg}$ (optimal, normal, or high-normal blood pressure values).

Education had a significant impact on prevalence of hypertension and blood pressure levels. Prevalence of hypertension significantly decreased with the education level. In subjects with primary education, the prevalence of hypertension was $70.24 \%$, in subjects with vocational education $56.96 \%$, in subjects with sec- ondary education $61.05 \%$, and in university educated people $55.83 \%$ (Fig. 1).

$48.48 \%$ of studied population was not aware of their hypertension. Significantly, more men than women had undiagnosed hypertension (53.42\% vs. $44.33 \%$ ) (Table 2 ). Undiagnosed hypertension was more prevalent among younger age group (Fig. 2).

As many as $54.08 \%$ of urban dwellers and $39.92 \%$ of rural dwellers had undiagnosed hypertension (Fig. 3). Interestingly, better educated groups had higher proportion of undiagnosed hypertension than less educated persons. The undiagnosed hypertension was found in $31.39 \%$ of primary educated group, $48.89 \%$ of vocational educated group, $50.00 \%$ of secondary education group, and $57.31 \%$ of university educated group (Fig. 4 ). Generally, patients with undetected hypertension were younger, more frequently male, and well educated.

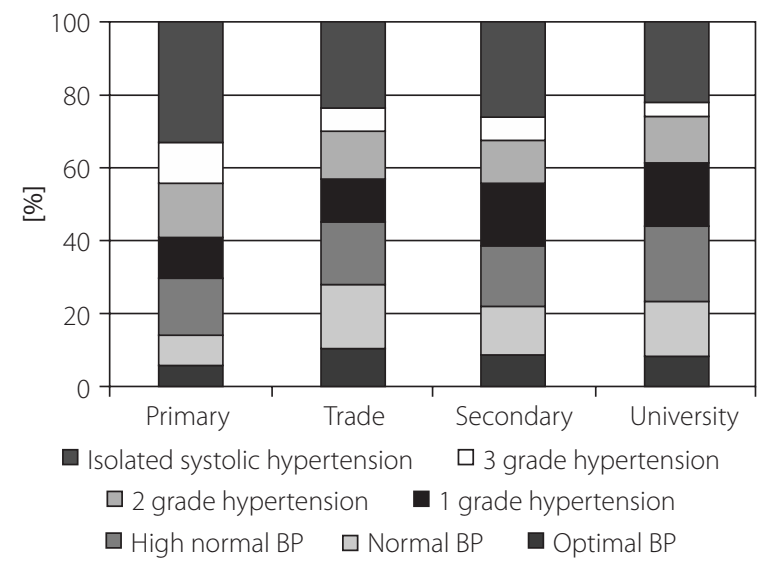

FIG. 1. The categories of hypertension due to education

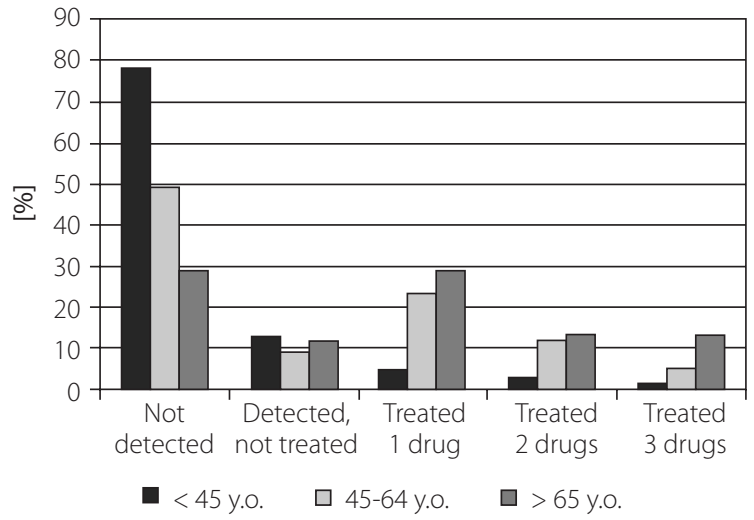

FIG. 2. Detection and treatment of hypertension due to age groups

TABLE 2. Detection and treatment of hypertension due to gender

\begin{tabular}{|l|c|c|c|c|}
\hline Blood pressure & Women & Men & All & $P\left(\chi^{2}\right)$ \\
\hline Not detected & $44.33 \%$ & $53.42 \%$ & $48.48 \%$ & \\
\hline Detected, not treated & $10.14 \%$ & $10.97 \%$ & $10.52 \%$ & \\
\hline Treated 1 drug & $24.51 \%$ & $19.78 \%$ & $22.35 \%$ & \\
\hline Treated 2 drugs & $14.07 \%$ & $10.79 \%$ & $12.57 \%$ & \\
\hline Treated 3 drugs & $6.96 \%$ & $5.04 \%$ & $6.08 \%$ & 0.01210 \\
\hline
\end{tabular}




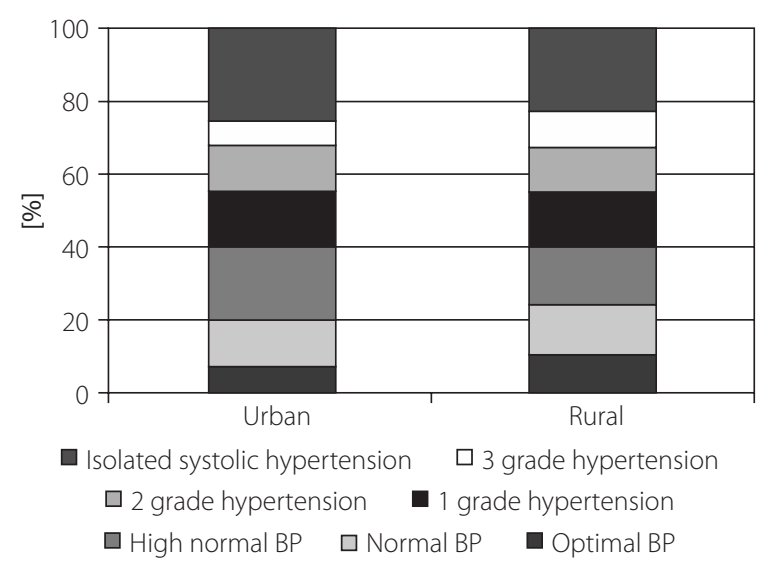

FIG. 3. The categories of hypertension due to dwelling-place

$10.52 \%$ was found to have diagnosed but not treated hypertension. No significant difference between rural and urban dwellers and male and female according to diagnosed but not treated hypertension were found.

$41.00 \%$ of studied population was treated with one, two, three, and more hypotensive medications $(22.35 \%$, $12.57 \%$, and $6.08 \%$, respectively). Gender differences are apparent: $45.54 \%$ of women were treated but only $35.6 \%$ of men (Table 2). The proportion of treated hypertension patients increased with age.

$0.74 \%$ of studied population was underweight, $28.06 \%$ had normal weight, $40.15 \%$ was overweight (BMI 25$\left.29.9 \mathrm{~kg} / \mathrm{m}^{2}\right)$, and $31.05 \%$ was obese $\left(\mathrm{BMI}>30 \mathrm{~kg} / \mathrm{m}^{2}\right)$. Abdominal obesity was observed at $68.75 \%$ of studied population defined, according to IDF criteria (males $\geq 94 \mathrm{~cm}$ and females $\geq 80 \mathrm{~cm}$ ) and $65.06 \%$ according to WHR ratio. The prevalence of hypertension increased with body weight. $41.20 \%$ of normal body weight, $62.52 \%$ of overweight, and $75.20 \%$ of obese individuals was hypertensive (Fig. 5).

The prevalence of diabetes, stroke, and ischemic heart disease was respectively $12.01 \%, 1.90 \%$, and $5.50 \%$ in studied population.

In hypertensive individuals, diabetes, stroke, ischemic heart disease was more prevalent comparing to normotensive individuals $(15.39 \%$ vs. $6.87 \%, 2.06 \%$ vs. $1.63 \%$, and $6.92 \%$ vs. $3.50 \%$, respectively).

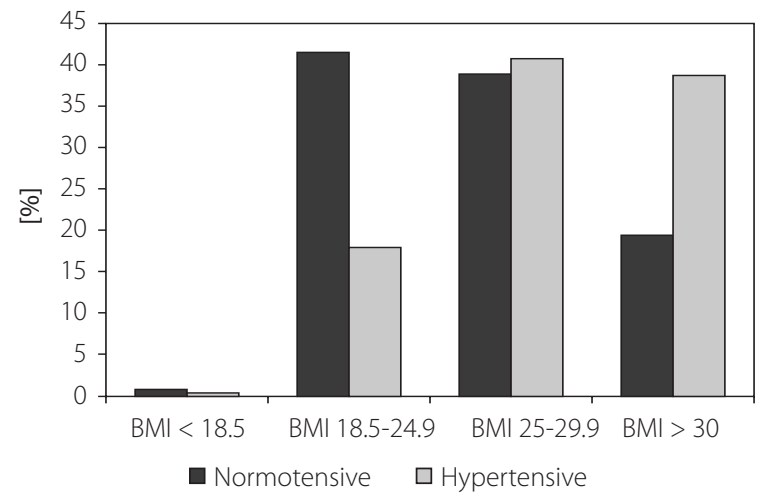

FIG. 5. Body mass index (BMI) in normotensive and hypertensive individuals

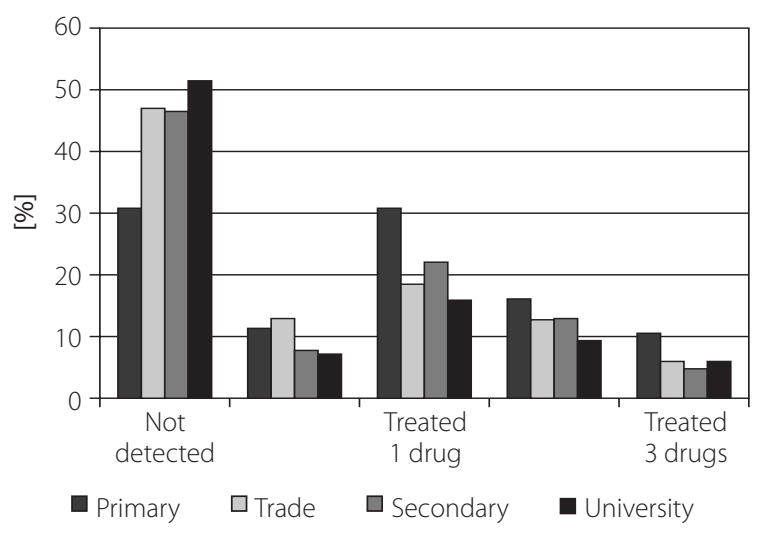

FIG. 4. Detection and treatment of hypertension due to education

\section{DISCUSSION}

Hypertension is a major cardiovascular factor and its prevalence differ in relation to age, sex, and education [15]. Also, urbanization may be considered as a risk factor of hypertension and cardiovascular diseases [16]. The analysis of the PURE cohort provides detailed information about prevalence's of hypertension, treatment, and characteristics of the population in the region Lower Silesia. Surprisingly, we found that hypertension, diabetes, and obesity are still highly prevalent, and hypertension awareness is very poor. The current project revealed hypertension prevalence of $60.3 \%$ in the studied population. The occurrence of hypertension in the PURE population was higher than described previously for Poland (NATPOL plus study - 45\% in 45-64 years old group, Pol-Monica-study - 34\%, WOBASZ study - 36\% [17-19] and NATPOL $11-32 \%$ [13]). However, the prevalence of hypertension as high as $61.7 \%$ was also reported in PONS study [14].

Among participants in older age, blood pressure was higher in men than in women. These data confirm other epidemiologic studies, which indicate a higher prevalence of hypertension among man comparing to women and age as a risk factor for hypertension.

The prevalence of not detected hypertension in the PURE population was $48.5 \%$. The results of NATPOL 2011 and PONS study showed lower prevalence $(30 \%$, $23.1 \%)$ of undiagnosed hypertension in Poland $[13,14]$. Undiagnosed hypertension was observed more frequent in men then in women, in the younger group of men, in well educated people, and in urban dwellers. This result shows that woman and older people are more interested in knowing their blood pressure, and more eager to measure blood pressure and indicate the need to implement action of detection hypertension in men, especially younger, well-educated urban dwellers. Higher prevalence of not detected hypertension in urban dwellers could indicate lack of interest of urban dwellers' health.

Surprisingly, the highest prevalence of undiagnosed hypertension was observed in the group of well-educated people. The results point at worse effectiveness of preven- 
tive measures in higher educated people, what indicate lower frequency of routine blood pressure in this group. Thus, it is necessary to improve detection of hypertension in high educated people. Similar results were observed in PONS study in population from Kielce province [14].

Several modifiable socioeconomic determinants, such as education and occupation, are associated with hypertension. Low socioeconomic status increases the risk of hypertension. The possible explanations for this fact includes association with poor lifestyle including more smoking, alcohol abuse, less healthy diet, less physical exercise, and therefore, increased risk for obesity and metabolic syndrome [20]. The another explanation could be a low birth weight and higher job strain among lower socioeconomic status groups. We have used education as a marker of socioeconomic status.

In our study, abdominal obesity was commonly observed. $71.19 \%$ of studied population had increased body weight (body mass index BMI $>24.9 \mathrm{~kg} / \mathrm{m}^{2}$ ), and $68.56 \%$ had abdominal obesity according to IDF criteria. In PONS study, 75.1\% had increased waist circumference [21].

Epidemiologic studies suggested that up to $50 \%$ of obese individuals, as defined by body mass index (BMI) $>27 \mathrm{~kg} / \mathrm{m}^{2}$, have concomitant HTN $[22,23]$. The prevalence of hypertension in PURE population was higher in overweight individuals. The high prevalence of increased body weight $(73 \%)$ could be the explanation for high prevalence of hypertension in studied population.

We have also observed higher prevalence of diabetes, stroke, and coronary artery disease prevalence in hypertensive groups. The prevalence of diabetes was $12.01 \%$ in studied population. This occurrence was higher than in previous studies (PONS - 8.4\%, PWBEC - 5.3\%, NATPOL $-5.6 \%)[24,25]$

These data confirm other epidemiologic studies, which indicate a higher prevalence of coronary heart disease, and stroke in hypertensive individuals and frequent coexistence of hypertension and diabetes.

Summarizing, many individuals with hypertension in Poland remain unaware of their condition. To improve prevention and detection of hypertension, more educational activities for the patients and heath care professionals are needed such as health education and screening services.

\section{CONCLUSIONS}

The studied group had high prevalence of hypertension (60.30\%). Hypertension was less frequent in studied women than in men. Level of education had significant impact on prevalence of hypertension. The highest percent of undiagnosed hypertension was at younger, well educated, male urban dwellers.

Thus, special attention should be given to groups most affected, undiagnosed, and inadequately treated to improve the knowledge, attitude, and behaviors of patients and health professionals.

\section{STUDY LIMITATIONS}

PURE study is a longitudinal prospective cohort study, which has been continued in follow-ups every three years. Nowadays, in this paper we present cross-sectional results from the baseline. Methodology of pressure measurements have been used throughout whole PURE project, which is common for over 150,000 participants overall. Because of extension of the study, it was chosen to conduct 3 measurements during one day of examination, of which an average value of pressure was calculated. This type of measurement was used in other epidemiological studies. Therefore, the definition of the hypertension used in this manuscript is different from the definition used for clinical purposes (two measurements on two separate days).

\section{FUNDING}

Detailed information about project funding of the entire PURE Project: The main PURE study and its components are funded by the Population Health Research Institute, the Canadian Institutes of Health Research, Heart and Stroke Foundation of Ontario, and through unrestricted grants from several pharmaceutical companies, Poland sub-study: Polish Ministry of Science and Higher Education (grant no. 290/W-PURE/2008/0), Wroclaw Medical University.

\section{DISCLOSURE}

Authors report no conflict of interest.

\section{References}

1. Roger VL, Go AS, Lloyd-Jones DM, et al. Heart disease and stroke statistics - 2012 update: a report from the American Heart Association. Circulation 2012; 125: e2-20.

2. Whelton PK. Epidemiology of hypertension. Lancet 1994; 344 : 101-106.

3. Isomaa B, Almgren P, Tuomi T, et al. Cardiovascular morbidity and mortality associated with the metabolic syndrome. Diabetes Care 2001; 24: 683-689.

4. Cuspidi C, Ambrosioni E, Mancia G, et al. APROS Investigators. Role of echocardiography and carotid ultrasonography in stratifying risk in patient with essential hypertension: The Assessment of Prognostic Risk Observational Survey. J Hypertens 2002; 20: 1307-1314.

5. Sowers JR, Zemel MB. Clinical implications of hypertension in the diabetic patient: a review. Am J Hypertens 1990; 3: 415-424.

6. Hypertension in Diabetes Study (HDS): I. Prevalence of hypertension in newly presenting type 2 diabetic patients and the association with risk factors for cardiovascular and diabetic complications. J Hypertens 1993; 11: 309-317.

7. Lago RM, Singh PP, Nesto RW. Diabetes and hypertension. Nat Clin Pract Endocrinol Metab 2007; 3: 667.

8. Mancia G, Grasii G. The new European Society of Hypertension/ European Society of Cardiology (ESH/ ESC) Guidelines. Ther Adv Cardiovasc Dis 2008; 2: 5-12. 
9. Mancia G, Laurent S, Gabiti-Rosei E, et al. Reappraisal of European Guidelines on hypertension management: A European Society of Hypertension Task Force document. J Hypertens 2009; 27: 2121-2158.

10. Kearney PM, Whelton M, Reynolds K, et al. Global burden of hypertension: analysis of worldwide data. Lancet 2005; 365: 217-223.

11. Wolf-Maier K, Cooper RS, Benegas JR, et al. Hypertension prevalence and blood pressure levels in 6 European countries, Canada and the United States. JAMA 2003; 289: 2363-2369.

12. Zdrojewski T, Szpakowski P, Bandosz P, et al. Arterial hypertension in Poland 2002. J Hum Hypertens 2004; 18: 557-562.

13. Zdrojewski T, Bandosz P, Gaciong Z, Wyrzykowski B. Rozpowszechnienie czynników ryzyka chorób układu sercowo-naczyniowego w Polsce w 2011 r. Zakres wieku 18-79 lat. NATPOL 2011 [Increase in cardiovascular diseases risk factors distribution in Poland in 2011. Age span 18-79. NATPOL 2011]. XV Międzynarodowy Kongres PTK [XV Congress of Polish Craniological Association (PTK)], 6-8.10.2011.

14. Szuba A, Martynowicz H, Zatońska K, et al. Prevalence of hypertension in a sample of Polish population - baseline assessment from the prospective cohort 'PONS' study. Ann Agric Environ Med 2011; 18: 260-264.

15. Kannel WB. Blood pressure as the cardiovascular risk factor. JAMA 1996; 275: 1571-1576.

16. Yusuf S, Reddy S, Ounpuu S, Anand S. Global burden of cardiovascular diseases Part I: General Consideration, the Epidemiologic Transition, Risk factor, and Impact of Urbanization. Circulation 2001; 104: 2746-2753.

17. Zdrojewski T, Szpakowski P, Bandosz P, et al. Arterial hypertension in Poland 2002. J Hum Hypertens 2004; 18: 557-562.

18. Wągrowska H, Rywik S. Występowanie nadciśnienia tętniczego $\mathrm{w}$ populacji prawobrzeżnej Warszawy na podstawie badań Pol-MONICA [Prevalence of arterial hypertension in Warsaw east-bank population based on Pol-MONICA]. Wiad Lek 1990; 43: 47-55

19. Polakowska M, Piotrowski W, Włodarczyk P, et al. Program epidemiologiczny oceniający częstość nadciśnienia tętniczego w Polsce w populacji osób dorosłych - badanie PENT. Część I. Charakterystyka częstości i stopień kontroli nadciśnienia tętniczego [Epidemiology program - assessment of arterial hypertension prevalence in adult Pols - PENT research. Part I. Arterial hypertension prevalence and arterial hypertension control rate]. Nadciśn Tętn 2002; 3: 157-166.

20. Nilsson PM. Adverse social factors can predict hypertension but how? Eur Heart J 2009; 30: 1305-1306.

21. Janszky I, Vatten L, Romundstad P, et al. Metabolic syndrome in Poland - the PONS Study. Ann Agric Environ Med 2011; 18 270-272.

22. Almgren T, Wilhelmsen L, Samuelsson O, et al. Diabetes in treated hypertension is common and carries a high cardiovascular risk: results from a 28-year follow-up. J Hypertens 2007; 25: 1311-1317.

23. Sowers JR, Haffner S. Treatment of cardiovascular and rena risk factors in the diabetic hypertensive. Hypertension 2002; 40 781-788.
24. Szybiński Z. Polskie Wieloośrodkowe Badania nad Epidemiologią Cukrzycy (PWBEC) - 1998-2000. Pol Arch Med Wewn 2001; 3: 751-791.

25. Zdrojewski T, Bandosz P, Szpakowski P, et al. Ocena wybranych problemów dotyczących wybranych terapii nadciśnienia tętniczego w Polsce na podstawie badania NATPOL III PLUS [Evaluation of selected problems in chosen arterial hypertension therapies in Poland based on NATPOL III PLUS project]. In: Więcek A, Kokot F (eds.). Postępy w nefrologii i nadciśnieniu tętniczym [Advances in Nephrology and Arterial Hypertension]. Tom 2. Medycyna Praktyczna, Kraków 2003; 11-15.

\section{AUTHORS' CONTRIBUTIONS}

$\mathrm{KZ}, \mathrm{RI}$ and WAZ prepared the research concept and design. MW collected data. KPZ and HM analysed data. HM, BRI and DR wrote the article. HM, BRI and DR participated in its critical revision. AS, KZ and WAZ finally approved it. 